\title{
Vegetational Responses Following Winged Elm and Oak Control in Oklahoma ${ }^{1}$
}

\author{
R. L. DALRYMPLE, DON D. DWYER, AND \\ P. W. SANTELMANN \\ Graduate student, Assistant Professor, and Associate \\ Professor of Agronomy, respectively; Oklahoma State \\ University, Stillwater.
}

Highlight

Total herbage production increased significantly following 92 to 100 percent control of winged elm, oak, and hickory trees. This increase, however, was mostly in less desirable grass and forb plants, even on reseeded plots. Natural recovery of desirable grasses after brush control on this type in Oklahoma appears to be a slow process. Reseeding may speed up forage plant establishment. but more research is needed.

There are an estimated $10 \mathrm{mil}-$ lion acres dominated by undesirable woody vegetation in Oklahoma (Elwell, et al. 1950). Much of the area in eastern Oklahoma is occupied dominately or subdominately by winged elm (Ulmus alata). This species occurs from eastern Texas, Oklahoma, and Kansas to the coast of North and South Carolina and parts of Florida (Brush, 1918; Shipman, 1959).

Grass production is suppressed when woody vegetation is dense. Control of woody plants, primarily oak (Quercus spp.) in Oklahoma, releases the grasses for increased utilization by livestock. When the oaks are controlled, the elm is also released and increases in stature and abundance on the area. This frequently causes a problem more severe than the oak because of winged elm resistance to currently used foliar applied herbi-

1 This study was supported in part by Central Research Fund-1 contributing to Okla. Agric. Expt. Sta. Project 1146, in cooperation with Weed Investigations, Grazing Lands, Crops Research Division, A.R.S., U. S. Dept. Agric. Special recognition is given Mr. H. M. Elwell of the U.S.D.A. Crops Research Division at Stillwater, Oklahoma, for assistance and guidance throughout the study. cides. Desirable grass stands are often very sparse on these wooded areas. Reseeding of desirable grasses may increase the chances for more rapid grassland improvement.

Some brush control research stresses the effect of herbicides upon the brush species treated (Frey, 1953; Waldrip, 1953). Other work emphasizes changes in herbage production, species composition, and stand density Crawford, 1960; Vogel and Peters, 1961; DaIrymple, 1961; Ehrenreich, 1959; and Elwell, 1953). Darrow and McCully (1959) stated that removal of brush overstory released moisture, light, and nutrients for use by more desirable range plants. Root plowing and reseeding increased the stocking rate from 33 to 5 acres per cow and also improved calf weights (Carter, 1958).

As hardwood crown cover decreases there is a corresponding increase in herbage production (Ehrenreich and Crosby, 1960). A release in both shortleaf pine (Pinus echinata) and grass has resulted when hardwoods were aerially treated with 2,4,5-T (E1well, 1962). Seeding of desirable grasses following brush control has been shown to contribute considerably to herbage production (Dalrymple, 1961; Vogel and Peters, 1961).

The major objective of this study was to determine the effect of winged elm and oak control and grass seeding upon percent vegetational composition, basal cover, and herbage production. The rate of woody species increase or invasion was noted after chemical treatment.
There was little desirable grass on the area at the outset. The herbaceous plants were fairly vigorous in openings, but were sparse and stunted under the tree canopy.

\section{Materials and Methods}

An area in southeast Oklahoma in the blackjack - post oak (Quercus marilandica-Q. stellata) vegetative type described by Duck and Fletcher (1943) was selected for the study. Species composition of the woody plants of the study area was 42 percent winged elm, 35 percent post and blackjack oak, 9 percent mockernut hickory (Carya tomentosa), 5 percent sumac (Rhus spp.), and 9 percent other woody species. The soil was Enders loam (non-modal) with a solum depth of 11 to 35 inches. ${ }^{2}$ The soil was classed as having low fertility with organic matter of 2.5 to 5.6 percent in topsoil and 1.0 to 2.6 percent in the subsoil. The $\mathrm{pH}$ (paste) of the topsoil and subsoil ranged from 5.0 to 5.7 and 4.6 to 4.8 , respectively.

Precipitation and maximum-minimum air temperatures were recorded daily at the study site. The area is in the 40 to 45 inch rainfall belt. Precipitation for the growing season (April through October) was slightly above the 1931-1952 average for the arca, but that for May and June was about half the long-time average. Precipitation for the 1963 growing season (April through $\mathrm{Au}-$ gust) was 7.42 inches below normal. Maximum and minimum air temperatures for the growing season of 1962 and 1963 exceeded the longtime average by 1 to 6 degrees Fahrenheit.

Three treatments and a check were applied in May, 1962 and were replicated five times on one-eighth acre plots (50 X 109 feet). They were:

1. "Check", all vegetation was allowed to grow and reproduce naturally.

2. All trees except very small seed-

${ }^{2}$ Soil classification by L. C. Singleton, Soil Conservation Service, McAlester, Oklahoma. 
lings were basally injected with undiluted triethylamine salt of 2,4,5-T in late May, 1962. All other vegetation was allowed to grow and reproduce. This treatment is referred to as "natural recovery".

3 . Trees were treated as in no. 2. The plots were then broadcast seeded by hand at the rate of 4.0 pounds pure-live-seed per acre of a native grass mixture primarily little bluestem (Andropogon scoparius) and Indiangrass (Sorghastrum nutans). Secding was done about one wcek prior to the 2,4,5-T treatment. This treatment is referred to as "native seeded".

4. Tree species were treated as above. The plots were then seeded as in no. 3 , using 7.5 pounds purelive-seed per acre of King Ranch bluestem (Bothriochloa ischaemum). This treatment is referred to as " $\mathrm{K}-\mathrm{R}$ seeded".

The brambles and small shrubs were cut near ground level with a scythe in late June, 1962, in the 2,4,5-T treated plots in an effort to reduce competition for better grass seedling establishment.

A 25 foot wide area was treated between check plots and injector treated plots, and around the ends and edges of a block. This was done to eliminate the effect of shading, moisture depletion, and nutrient use by untreated trees whose roots extended in to the treated areas.

Vegetational analyses were made at the initiation of the study and each fall of the two years following. A 50 foot line transect was used to determine species composition and basal cover of grass and grass-like species (Cyperaceae and Juncaceae). Two permanently located lines were read per plot making 500 linear feet per treatment. Herbaceous vegetation was measured in millimeters. A $50 \times 6$ foot belt transect was used to determine species composition and apparent kill of tree species and large shrubs (Rhus spp.). Abundance of broadleaved herbaceous plants, woody species up to $1 / 2$ inch diameter, and grass seedlings was determined using 10 square foot frames per plot ( 50 per treatment). Five equally spaced square foot frames were read on each side of the center line transect.

Five randomly located, $11.5 \times 24$ inch quadrats per plot, clipped at ground level, were used for herbage production determinations. Herbage was hand separated into the following categories: beaked Panicum (Panicum anceps); rosette Panicums ( $P$. spp.); big and little bluestem (Andropogon gerardi and A. scoparius), switchgrass ( $P$. virgatum), and Indiangrass (Sorghastrum nutans); broomsedge bluestem (Andropogon virginicus), nimblewill (Muhlenbergia schreberi); other grass species, grass-like plants, legumes, and other forbs. In $K-R$ seeded plots King Ranch bluestem production was measured.

Duplicate samples for soil moisture determination were taken from the upper three feet of each treatment with a soil tube and hammer and oven dried at $105^{\circ} \mathrm{C}$. for 24 hours. Soil samples were taken from all check plots and analyzed for $\mathrm{pH}$, available phosphorus, organic matter, and nitrogen.

\section{Results and Discussion}

Available moisture in the upper three feet of soil was lower in the check treatment at all sampling dates except January 21,1963 , when soil moisture was high in all treatments (Figure 1). There was a general downward trend in soil moisture from April to September, 1963. During the last four months of 1963, the soil moisture in the check treatment was below the wilting percentage level while all other treatment had some available moisture, indicating the trees of the check treatment used more mois- ture than the herbaceous types of vegetation.

Winged elm, blackjack, and post oak varied from 64 to 83 percent of the total woody plant numbers which ranged from 3659 to 4936 stems per acre on the various plots. Tree kill in chemically injected plots was over 92 per cent in the fall, 1963. Hickory (Carya sp.) was somewhat resistant to the herbicide and required a re-treatment in 1962. Refoliation of some oak and hickory in 1963 resulted in a slightly lower percent kill in 1963 than 1962 . The dead hickory and winged elm were decaying and falling about six months after treatment. No sprouting was evident on any treated trees.

Herbage Production - Total herbage production per acre (oven dry) for natural recovery, native seeded, and $\mathrm{K}-\mathrm{R}$ seeded treatments was two to three times that of the check the first year (Table 1). This increased as much as seven fold in the natural recovery treatment the second year following treatment. The increased forage in the three treated plots was primarily less desirable grass and forb species. Forbs made up about half the yield of the K-R treatment in 1963. There was a decrease in the yield of the check in 1963 , probably caused by soil

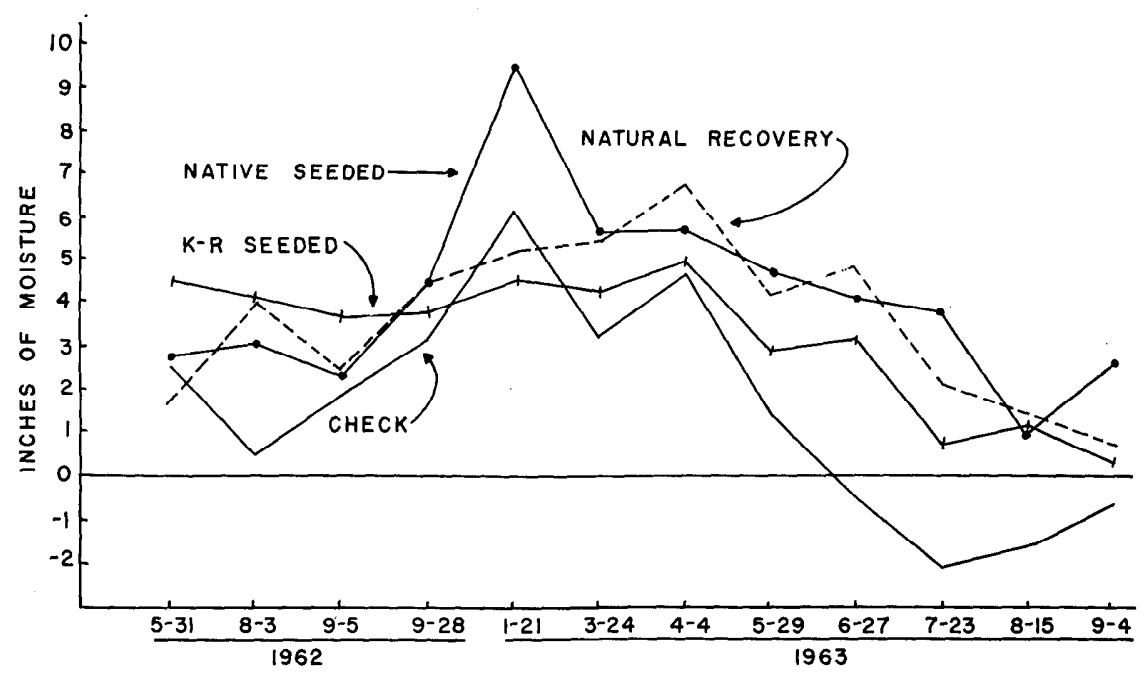

Figure 1. Inches of available soil moisture in the upper three feet of soil. 
Table 1. Herbage production in pounds per acre oven dry. Clippings made September 3, 1962 and 1963.

\begin{tabular}{|c|c|c|c|c|c|c|c|c|}
\hline \multirow[b]{3}{*}{ Species } & \multicolumn{8}{|c|}{ 2,4,5-T Tree Injection Treatments } \\
\hline & \multicolumn{2}{|c|}{ Check } & \multicolumn{2}{|c|}{ Natural } & \multicolumn{2}{|c|}{$\begin{array}{l}\text { Native } \\
\text { Seeded }\end{array}$} & \multicolumn{2}{|c|}{$\begin{array}{c}\mathrm{K}-\mathrm{R} \\
\text { Seeded }\end{array}$} \\
\hline & 1962 & 1963 & 1962 & 1963 & 1962 & 1963 & 1962 & 1963 \\
\hline Rosette panicums & 89 & 97 & 169 & 501 & 315 & 491 & 261 & 571 \\
\hline Broomsedge & 50 & 41 & 137 & 191 & 402 & 184 & 77 & 79 \\
\hline Grass-like plants & 60 & 49 & 124 & 120 & 35 & 64 & 186 & 46 \\
\hline Beaked & 31 & 14 & 96 & 92 & 13 & 23 & 60 & 65 \\
\hline Nimblewill & 17 & 7 & 92 & 170 & 197 & 411 & 88 & 199 \\
\hline Age, Asc, Snu1 1 & ..... & $\ldots$. & 144 & 177 & ....... & 2 & 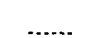 & ....... \\
\hline King Ranch Bluestem & $\ldots$ & $\ldots$. & $\ldots$ & ....... & ........ & ....... & 15 & 8 \\
\hline Other grasses & 98 & 53 & 507 & 592 & 123 & 54 & 252 & 149 \\
\hline Forbs & 124 & 87 & 76 & 570 & 119 & 330 & 245 & 1094 \\
\hline TOTAL & 469 & 348 & $1342 *$ & $2413^{*}$ & $1204^{*}$ & $1559^{*}$ & $1184^{*}$ & $2211^{*}$ \\
\hline
\end{tabular}

${ }_{1}^{1}$ Age, Asc, and Snu represent big bluestem, little bluestem and Indiangrass, respectively.

*Total production significantly greater than the check at the .01 level for all treatments and years.

moisture deficiency in the latter part of the growing season.

Grasses making up most of the yield were rosette panicums, broomsedge bluestem, grass-like plants, and "other grasses"; the other grasses were primarily slimspike threeawn (Aristida longispica), poverty Danthonia (Danthonia spicata), Virginia wildrye (Elymus virginicus), fringeleaf Paspalum (Paspalum ciliatifolium), bristlegrass (Setaria spp.), longspike Tridens (Tridens strictus), purpletop ( $T$. flavus), and others. Forbs yielded a sizeable portion the second year in all treatments, primarily basketflower (Centaurea americana), Croton spp., American burnweed (Erechtites hieracifolia), white snakeroot (Eupatorium rugosum), sunflowers ( $\mathrm{He}$ lianthus spp.), prickly lettuce (Lactuca scariola), Missouri goldenrod (Solidago missouriensis), and wild legumes.

Seeding of native grass did not contribute to herbage yield the first year, but did slightly the second year. The decrease in $\mathrm{K}-\mathrm{R}$ bluestem the second year may have been due to the adverse moisture relationships. The natural recovery treatment yielded more Indiangrass, big and little bluestem than did the native seeded treatment. Generally, all treatments yielded
An upward trend in basal cover was common in all tree injection treatments from less than one percent initially to 2.0 to 2.8 percent in 1963 .

Percent species composition of beaked panicum decreased in 1962 but increased in 1963 in treatments other than the check because it occurs in large clumps and is not as widely distributed as the rosette panicums and other grasses. The more widely dispersed single or few stemmed grasses increased to many stems and accumulated a large area faster than the beaked panicum. In 1963 after the other grasses had made considerable increase, beaked panicum increased in area and in percent species composition.

Desirable grasses such as big bluestem, little bluestem, Indiangrass, and King Ranch bluestem tended to increase in the species composition, but were not dominant at any time. Native grass seedlings in the "native seeded" plots were not present until the second year and then made up only 3 per cent (Table 2). Seeding of $\mathrm{K}-\mathrm{R}$ bluestem resulted in 2 and 5 percent of the species composition in first and second year, respectively.

Seeding of the grasses in midMay, 1962, was somewhat later than desirable, as limited precipitation in May and June

Table 2. Percent basal cover and species composition of grasses and grasslike plants. Dates represent initial and final readings.

\begin{tabular}{|c|c|c|c|c|c|c|c|c|}
\hline & \multicolumn{8}{|c|}{ 2,4,5-T Tree Injection Treatments } \\
\hline & \multicolumn{2}{|c|}{$\begin{array}{c}\text { Check } \\
6 / 4 / 629 / 3 / 63\end{array}$} & \multicolumn{2}{|c|}{$\begin{array}{c}\text { Natural } \\
\text { Recovery } \\
6 / 4 / 629 / 3 / 63\end{array}$} & \multicolumn{2}{|c|}{$\begin{array}{c}\text { Native } \\
\text { Seeded } \\
6 / 4 / 629 / 3 / 63\end{array}$} & \multicolumn{2}{|c|}{$\begin{array}{c}\text { K-R } \\
\text { Seeded } \\
6 / 4 / 629 / 3 / 63\end{array}$} \\
\hline $\begin{array}{l}\text { Basal Cover } \\
\text { Species }\end{array}$ & 0.8 & 1.0 & 0.8 & 2.6 & 0.4 & 2.0 & 0.4 & 2.8 \\
\hline Beaked panicum & 42 & 34 & 13 & 18 & 6 & 28 & 13 & 19 \\
\hline Rosette panicums & 10 & 24 & 14 & 32 & 32 & 32 & 32 & 42 \\
\hline Nimblewill muhly & 11 & 5 & 7 & 15 & 10 & 17 & 9 & 11 \\
\hline Broomsedge bluester & $\mathrm{m} 5$ & 8 & 4 & 12 & 7 & 7 & $\ldots$ & 4 \\
\hline Purpletop & $\cdots$ & $\ldots$. & 22 & 6 & 3 & 4 & 1 & 9 \\
\hline Age, Asc, and Snu1 & 1 & $\cdots$ & 1 & 5 & $\ldots$. & 3 & $\ldots$ & ..... \\
\hline King Ranch Bluester & m.... & $\cdots$ & $\cdots$ & $\cdots$ & $\cdots$ & $\cdots$ & -... & 5 \\
\hline Other grasses & 2 & 2 & 5 & 3 & 2 & 1 & 3 & 3 \\
\hline Grass-like plants & 31 & 27 & 35 & 10 & 39 & 8 & 42 & 8 \\
\hline
\end{tabular}

1Age, Asc, and Snu are big bluestem, little bluestem, and Indiangrass, respectively. 
caused adverse conditions for seed germination. Limited soil moisture during 1963 made congrass establishment. During the second year the $K-R$ bluestem plants were somewhat localized and in relatively large bunches. The native grass plants were in smaller clumps and more widely dispersed. The dispersion could have considerable influence on the increase in stand of these grasses in future years.

Abundance.-Number of $\mathrm{K}-\mathrm{R}$ bluestem plants per square foot was 0.08 and 0.2 the first and second years, respectively. This was much lower than desired for proper grass establishment. $\mathrm{Na}$ tive grass seedlings were observed but did not appear in the sampling (Table 3).

At the end of two years, abundance of winged elm seedlings was much greater in the check treatment. This suggests that an increased grass stand competes with winged elm seedlings to the point of reducing or limiting elm stand density.

Generally, forbs increased in abundance in all tree injection treatments. Legumes, primarily Lespedeza species, increased in abundance the first year and decreased the second year. Stature of forbs was much greater in treatments of tree control. Some specimens of prickly lettuce and American burnweed were over ditions very unfavorable for

10 feet tall on plots where trees were killed.

\section{Summary and Conclusions}

Research was conducted to determine the effect of brush control and reseeding on herbage production, percent species composition of grasses, and relative abundance of forbs and smallstemmed woody plants. A check and the following three treatments were applied in May, 1962: natural recovery, native seeded, and King Ranch bluestem seeded. Trees were killed by $2,4,5-\mathrm{T}$ injection on all treatments but the check. Observations were made on invasion of woody species and grass establishment by reseeding. Available soil moisture in the upper three feet of the profile of the check treatment was nearly always lower than that of the 2,4,5-T amine injection treatments. Soil moisture was below the wilting percentage four months of 1963 .

A tree kill of 92 to 100 percent resulted in 2 to 3 times more total forage in the treated plots than the check the first year and as much as seven fold the second year. Most of the herbage yield was made up of less desirable grass and forb species. Basal cover of grasses increased from less than one percent initially to 2.0 to 2.8 percent the second year on the injector treated areas. There was more increase the second year than the first. Seed-

Table 3. Abundance of small stemmed woody plants and forbs per square foot. Dates represent initial and final readings.

\begin{tabular}{|c|c|c|c|c|c|c|c|c|}
\hline \multirow[b]{2}{*}{ Species } & \multicolumn{8}{|c|}{$2,4,5-T$ Tree Injection Treatments } \\
\hline & \multicolumn{2}{|c|}{$\begin{array}{c}\text { Check } \\
6 / 4 / 629 / 3 / 63\end{array}$} & \multicolumn{2}{|c|}{$\begin{array}{c}\text { Natural } \\
\text { Recovery } \\
6 / 4 / 629 / 3 / 63\end{array}$} & \multicolumn{2}{|c|}{$\begin{array}{c}\text { Native } \\
\text { Seeded } \\
6 / 4 / 629 / 3 / 63\end{array}$} & \multicolumn{2}{|c|}{$\begin{array}{c}\text { K-R } \\
\text { Seeded } \\
6 / 4 / 629 / 3 / 63 \\
\end{array}$} \\
\hline \multicolumn{9}{|l|}{ Woody: } \\
\hline Winged elm & .58 & 1.4 & .56 & .20 & .40 & .22 & .78 & .18 \\
\hline Oak spp. & & 0.6 & .06 & .02 & .03 & .04 & .08 & \\
\hline Other trees & .06 & 0.1 & .06 & $\ldots$. & .... & .06 & .... & .02 \\
\hline Brambles & .32 & .36 & .28 & .22 & .42 & .36 & .48 & .30 \\
\hline $\begin{array}{l}\text { Shrubs and vines } \\
\text { Forbs: }\end{array}$ & .16 & .02 & .06 & .16 & .18 & .12 & .34 & .52 \\
\hline Croton spp. & $\cdots$ & .76 & $\cdots$ & .10 & $\cdots$ & .04 & $\ldots$. & .04 \\
\hline American burnweed & d $\quad \ldots .$. & $\ldots$. & $\ldots$. & .20 & $\ldots$. & .40 & $\ldots$. & .26 \\
\hline White snakeroot & .... & .08 & $\ldots$ & .06 & $\ldots$. & .34 & .... & .04 \\
\hline Other forbs & 1.48 & .92 & 1.46 & .94 & 1.58 & .42 & 2.64 & .54 \\
\hline TOTAL & 3.16 & 3.90 & 2.20 & 1.96 & 2.62 & 2.24 & 3.80 & 1.70 \\
\hline
\end{tabular}

ing of native grass did not contribute to yield or species composition until the second year. Seeded King Ranch bluestem made some contribution both years.

Big bluestem, little bluestem, Indiangrass, and King Ranch bluestem tended to increase in the species composition but were not dominant at any time. Grasslike plants decreased in percent composition. These changes show the response of the various species to the altered environment. Generally, all forbs increased in the 2,4,5-T injection treatments after the treatment. One forb, American burnweed, increased in the injection treatments each year but did not occur in the check at any time. Winged elm seedlings were much more abundant in the check treatment, suggesting that increased herbaceous vegetation of the other treatments competes with the elm seedlings to the point of limiting or reducing their stand density.

The results of this study indicate that natural recovery of desirable grasses following brush control on this vegetative type is a slow process. This is especially true where so little in the way of desirable species is present at the time of treatment. Reseeding offers an opportunity to speed up the establishment of forage species but more research is needed to find a successful and economical reseeding technique that can be used with chemical control of elm and oak.

\section{LITERATURE CITED}

Brush, W. O. 1918. Utilization of elm. U.S. Dept. Agric. Bul. 683. $43 \mathrm{pp}$.

Carter, M. G. 1958. Reclaiming Texas brushland range. Jour. Range Mangt. 11: 1-5.

Crawford, H. S. 1960. Effect of $2,4,5-T$ sprays on forage production in west-central Arkansas. Jour. Range Mangt. 13:44.

DALRYMPLE, A. V. 1961. Forest ranges may increase forage yields. Agri. News 14(3). Agri. Dept. Southwest Mo. State College. Springfield, Mo.

Darrow, R. A. AND W. G. McCully. 
1959. Brush control and range improvement on the post-oak, blackjack area of Texas. Texas Agri. Expt. Sta. Bull. 942. 16 pp.

Duck, L. G. AND J. B. Fletcher. 1943. A game type map of Oklahoma. The Division of Wildlife Restoration. State of Oklahoma Game and Fish Dept. Oklahoma City, Okla.

EHRENREICH, J. H. 1959. Releasing understory pine increased herbage production. Cent. States Forest Expt. Sta. Note 139. 3 pp.

EhrenReICH, J. H., AND J. S. CROSBy. 1960. Herbage production is related to hardwood crown cover. Jour. For. 58: 564-565.
Elwell, H. M. 1953. New herbicide controlled oak brush and resulted in increased native grass production. Weeds 2: 302-303.

Elwell, H. M. 1962. Control of hardwoods with $2,4,5-\mathrm{T}$ in aerial applications for pine release and native grass improvement. Proc. 15th Southern Weed Conf. pp. 161-162.

Elwell, H. M., H. A. DANIEl, AND M. B. Cox. 1950. Brush control and pasture development in the Red Plains. Agron. Jour. 42: 390394.

Frey, W. K. 1953. Effects of herbicidal applications on common per- simmon. Jour. Range Mangt. 6: 437.

ShIPMAN, R. D. 1959. Silvical characteristics of winged elm. Southeast. For. Expt. Sta. Sta. Paper No. 103. $2 \mathrm{pp}$.

Vogel, W. G., AND E. J. Peters. 1961. Spraying, seeding and fertilization increase forage on Ozark forest ranges. U.S. Forest Serv. Cent. States Forest Expt. Sta. Note 152. 2 pp.

WALDRIP, W. J. 1953. Methods and results of chemical treatments on certain brush species in the vicinity of College Station, Texas. Jour. Range Mangt. 6: 456. 